\title{
The influence of parliamentarians on the development of financial management regulations for executive agencies
}

Tjerk Budding and Jos Klink

Zijlstra Center, Vrije Universiteit Amsterdam, Amsterdam, The Netherlands

\begin{abstract}
Purpose - The involvement of politicians in the introduction and use of financial management techniques in the public sector deserves more attention. This paper analyses the influence of members of Parliament (MPs) on the development of financial management regulations for Dutch central government executive agencies.

Design/methodology/approach - This paper uses desk research and analyses formal evaluation reports, as well as minutes of meetings of Parliament to analyse the influence of MPs on the changes in financial management regulations.

Findings - MPs' influence on the change of prescriptions seems to have been small. The authors observe that modifications were most often already formulated in general evaluation reports by the Ministry of Finance, in advance of parliamentary debates. The analysis also reveals that the criteria to be met by the executive agencies became more detailed in the initial years of the agency model and became more global in recent years. Research limitations/implications - This paper aims to contribute to the literature on the influence of politicians on financial management regulations.

Practical implications - The paper shows that the influence of MPs on the prescriptions is quite small in daily practice and therefore, their role in the legislative process, as far as financial management techniques are concerned, is limited.

Social implications - The results show that politicians are both in charge of, as well as subject to NPMinspired financial management regulations, whereas their influence on the rules is small. The authors advise to further analyse this, as well as to explore how their role can be enlarged.

Originality/value - The interplay between politicians and financial management techniques in general, and the influence of MPs on the legislative process in specific, is an underresearched area. This paper aims to contribute to this literature and shows that the influence of MPs on the development of financial management regulations is limited. Several changes were made in these prescriptions in a period of more than 25 years, whereas discussions in the Parliament hardly played a role in these modifications.
\end{abstract}

Keywords Parliamentary influence, Financial management regulations, Efficiency, Agencies, Full cost information, Accrual accounting

Paper type Research paper

\section{Introduction}

Like many other countries, The Netherlands have experienced a wave of New Public Management (NPM) reforms from the early 1980s onwards. Although these were not as farreaching as in Anglo-Saxon countries such as the UK, Australia and New Zealand (e.g. van Helden and Jansen, 2003; Groot and Budding, 2008), many reforms have been implemented, including the introduction of performance management instruments, the use of accrual accounting for reporting purposes, the use of full cost information [1] and the contracting out of governmental activities. An important driver for these reforms seems to be the expectation that

(C) Tjerk Budding and Jos Klink. Published by Emerald Publishing Limited. This article is published under the Creative Commons Attribution (CC BY 4.0) licence. Anyone may reproduce, distribute, translate and create derivative works of this article (for both commercial \& non-commercial purposes), subject to full attribution to the original publication and authors. The full terms of this licence may be seen at http://creativecommons.org/licences/by/4.0/legalcode.

Received 28 May 2019 Revised 29 September 2019 8 January 2020 20 March 2020

Accepted 23 March 2020

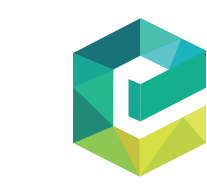

Journal of Public Budgeting Accounting \& Financial Management Vol. 32 No. 3,2020 pp. $421-438$

Emerald Publishing Limited 1096-3367

DOI 10.1108/JPBAFM-05-2019-0085 
JPBAFM 32,3 these would lead to efficiency improvements (e.g. ter Bogt, 1999; Lapsley, 2009), even though such gains were hard to prove in daily practice (ter Bogt, 1999; Groot and Budding (2008). Even though many doubts about the success of reforms were raised (e.g. see Lapsley, 2009) and several new paradigms were introduced, such as new public governance (Osborne, 2006) and public value management (Moore, 1995), governments all over the world still continued to use NPM-inspired instruments. Instead of a replacement of NPM thinking and techniques, new paradigms were actually supplemented to the existing ones (Hyndman et al., 2014). A recent study on the British situation by Hyndman and Liguori (2016) showed that NPM, even in recent years, remained the dominant public management paradigm in government reform discussions.

One of the main NPM reforms was the autonomization of governmental units. In The Netherlands, both central and local governments decided to put departments that carried out specific activities at some distance from their parent organizations. A distinction can be made here between internal and external autonomizations:

(1) Internal autonomization renders managerial freedom to units within the governmental organization remaining under the full ministerial responsibility;

(2) External autonomization refers to the establishment of organizations charged with policy implementation as a main task, paid for by the government, but operating at a distance from that the same government without an immediate hierarchical relationship (van Thiel, 2004).

This paper focusses on executive agencies which are a form of internal autonomization on the central government level. Starting in 1994 with four executive agencies, in 201830 agencies existed accounting for $43 \%$ of the total number of civil servants at the central government level [2]. This makes executive agencies an important part of the Dutch central government. Not only the implementation of the agencies can be seen as an NPM-inspired reform in itself, agencies were also mandated by law to use several NPM-inspired techniques, such as the use of accrual accounting and full cost information. Even today, when the heyday of NPM seems to be over, the regulations for these entities still prescribe the use of many instruments that were already compulsory in the 1990s, albeit in a more relaxed form.

Whereas NPM reforms had many implications for all actors involved in governmental organizations, the attention in the academic literature for the role of politicians is quite limited. The studies that are available focus on politicians' use of financial and non-financial information (e.g. see Van Helden, 2016) and their role in the budgeting and accounting cycle (Liguori et al., 2009). To the best of our knowledge, the literature on the role of politicians in the development of financial management regulations is less or even missing. This is surprising, as politicians have at least two main responsibilities and interests. First, they are the ultimate responsible actors in lawmaking and changing, including regulations related to financial management practices which had become more important under the influence of NPM thinking. Second, politicians belong to the main stakeholders of financial management rules because this kind of regulation determines how information is provided to them (e.g. using cash or accrual accounting) and how they can exercise control. Therefore, politicians are both in charge of, as well as subject to NPM-inspired financial management regulations. This paper aims to explore which role politicians play in the process of lawmaking and changing, as far as financial management techniques are concerned. Hereby, we limit our scope to the influence of members of Parliament (MPs). In The Netherlands central government departments cannot gain the agency status without an approval from parliament, therefore we focus our attention on these politicians. As previous literature has not yet focussed on this specific group, this study should be considered exploratory in nature.

In this paper, we analyse how prescriptions for financial management issues concerning executive agencies developed in a period of more than 25 years (1992-2018). Hereby, we focus 
on the influence of interventions by MPs during political debates and what role the results of evaluation studies on the agency model played in this. We do so by following the policy cycle (e.g. see Howlett et al., 2009; Wellstead and Stedman, 2015; for a rather similar model see Birckland, 2005). This cycle distinguishes the following phases (refer to Figure 1): (1) agenda setting, in which issues and problems are put on the political agenda, (2) policy formulation, (3) decision-making by politicians, (4) policy implementation and (5) monitoring and evaluation. This latter stage may not only lead to insights that may be picked up during the next policy cycle, but it could also directly lead to changes in policy formulation and policy implementation phases. In this paper, we focus on the fifth phase of this model, more specifically which insights were provided by formal general evaluation studies of executive agencies and how these studies played a role in discussions in the Parliament on the development of the regulation.

In our analysis, we focus on four specific themes. These themes are considered as main elements, both in the NPM theory and in the regulation of executive agencies in The Netherlands: (1) governance model, (2) accrual accounting, (3) full cost information and cost systems and (4) efficiency.

The first three themes were selected as these are identified as main elements of NPM reforms (Hood, 1995; Groot and Budding, 2008) and moreover, are compulsory under the Dutch law for executive agencies. The specific reason for studying efficiency is that NPM expects that the implementation of businesslike methods will lead to performance improvements (e.g. Lægreid and Verhoest, 2010). In the Dutch case, these improvements also seem to be the most important driver for setting up agencies in The Netherlands in the 1990s (ter Bogt, 1999) and are still considered to be so nowadays. We examine how the criteria were applied in the daily practice, hereby analysing to what extent these were implemented. We do so by using the results from general evaluation studies conducted by or commissioned by the Ministry of Finance, minutes of meetings of Parliament and letters from the Minister of Finance. Specifically, we analyse the role the insights from the general evaluation studies play in discussions in the Parliament and how this leads to changes in the regulation.

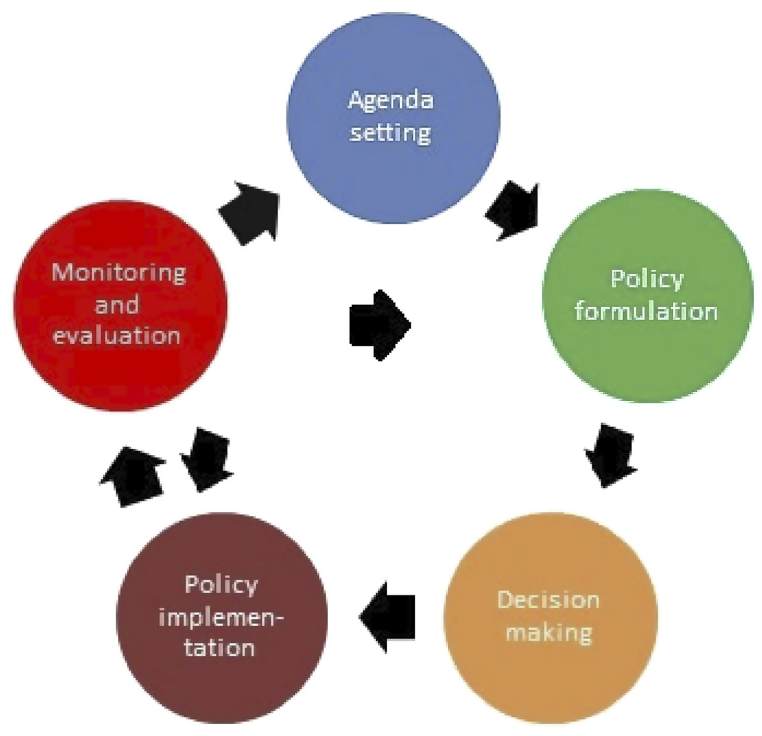

Figure 1. Phases of the

Source(s): Howlett et al., 2019 policymaking process

The influence of parliamentarians 
JPBAFM 32,3
Our analysis reveals several findings. First and foremost, we show that the influence of political discussion on the adjustments of the regulation was minimal. This suggests that the influence of Parliament in the making and changing of financial management regulation is limited. Second, it shows that it was difficult in the daily practice to prove that the implementation of executive agencies resulted in efficiency gains. Formal evaluation studies used moderate terms on this issue, such as the conclusion of the 2002 evaluation that "the agency model contributes to a more efficient execution because the critical success factors that contribute to an efficient operational management are part of the model and the conditions for implementation" [3]. These rather positive conclusions may have played a role in how parliamentarians dealt with their policymaking responsibilities. Third, we show how the specific regulations were changed several times. Starting from more "general" and "broad" terms in the early 1990s to "specific" and "detailed" 15 years later, the present criteria are once more stated in more general and broad terms. This development seems to show a clear "searching" trend.

The paper proceeds as follows. First, after a short introduction of agencies and NPM in The Netherlands, we provide a short historical overview of the development of the mandated criteria to obtain the status of an executive agency. We then present our findings on the four previously mentioned NPM themes regarding their regulation, results of evaluation and the influence of MPs.

\section{Agencies: introduction and prescriptions}

Introduction and formalization of agencies

Although agencies as an organizational form already existed in most countries earlier than the era of NPM, the NPM doctrine and related reforms changed the motives and the ideal-type governance of agencies (Verhoest, 2018). In addition, this formed a stimulus for the implementation of more agencies (Lægreid and Verhoest, 2010). In academic literature, the phenomenon of agencification has extensively been researched. Studies especially analysed the drivers behind agencification in countries, i.e. which tasks were put in agencies and why, how much autonomy and control agencies have and to what extent agencification leads to beneficial economic effects (e.g. Lægreid and Verhoest, 2010; Verhoest, 2018). With regard to the latter issue empirical evidence of positive effects is "rather patchy and overall results of studies are inconclusive" (Verhoest, 2018, p. 338).

Like in many other countries, agencification was an important element of the NPM reforms in The Netherlands. These reforms were implemented from the early 1980s onwards, a time when the country had already experienced an economic crisis for a couple of years. In the Dutch context, NPM was strongly motivated by the increasing scarcity in public budgets and dominated by economic reasons, leading to a central position of efficiency as a main goal for NPM. This central position of efficiency can not only be observed in The Netherlands but also in other countries (Lapsley, 2009).

As mentioned in the Introduction, a distinction between internal and external autonomizations must be made, both of which can be observed in The Netherlands. At the national level in The Netherlands, agencies and autonomous administrative authorities ("zelfstandige bestuursorganen" or "ZBO's" in Dutch) are examples of internal and external autonomizations, respectively. In the remainder of this paper we focus on internal autonomization solely.

As we will show later, the way internal autonomization was implemented in The Netherlands has much in common with what Pollitt et al. (2004) call the tripod model. Policy execution was assigned to executive agencies, whereas policy formulation remained within the ministry. Another important characteristic was that comprehensive managerial freedom was assigned to the agency. Finally, contractualism and results-based steering were 
important elements in the model in which three roles were distinguished, namely, those of (1) the executor (by the executive agency), (2) the client (commissioning party) who makes performance agreements with the executor and pays for services provided and (3) the owner (the parent ministry) who has an oversight role, hereby especially focussing on efficiency and continuity issues.

The term "executive agency" was used for the first time in 1992 in a report by a study group of senior officials called "Verder bouwen aan beheer" ("building further on management"), which explored the possibilities of introducing concepts of the resultorientated management in the Dutch Central Government. It was difficult for the study group to make exactly clear which organizations should be eligible for transferring into executive agencies:

"The big question is of course which parts of the Central Government should be considered for being transferred to agencies. For the study group this question is hardly answerable. That is, the preceding question is whether activities should be carried out by the government; a question that should be considered case by case. But also, for activities that remain within the government, it is difficult to indicate beforehand whether a certain type of government service is applicable for the status of an agency" [4].

However, the main goal of the report was to formulate recommendations for reaching a higher efficiency in the production of public goods and services, primarily by introducing instruments and alternative rules for public management in specific situations.

The Minister of Finance and the Parliament's public finance committee debated the report in 1992. The committee did not raise any objections to introduce agencies within central government departments. It only requested the Minister of Finance to give the status of executive agency a legal basis so that no agencies could be founded without the permission of the Parliament for each individual case. Another statement of MPs was to be careful and evaluate the model well before introducing a broad application [5]. Later on in 1992, the Minister of Finance and the Minister of the Interior [6] formulated three criteria that have to be met in order to transfer a department of central government into an executive agency [7]:

(1) The products and services should be measurable;

(2) A real opportunity for performance improvements should be possible;

(3) The administration and information systems should meet criteria that belong to this form of the result-orientated management.

After introducing and starting the first four agencies [8] in 1994, the term "agency" was formally introduced in the modified version of the comptabiliteitswet [9], the accountability law that comprises the legal rules for central government budgeting and reporting.

\section{The development of compulsory criteria}

The criteria, compulsory to obtain the status of executive agency, were changed several times over the years. We present the main criteria related to the four selected NPM themes in Table 1. In this table we distinguish several time periods. Government departments that want to obtain the agency status have to prove that they can meet these criteria in order to be successful as an agency. Preceding the start of an agency the Ministry of Finance executes assessments to assure all criteria are fulfilled.

The first two criteria, i.e. not only the prescription to use a specific governance model, but also the condition to have measurable products and services, both belong to our first theme (governance model). The third criterion reads as "an administration capable of producing specific management criteria", but this description is actually about the requirement to use accrual accounting. The fourth criterion relates to full cost information and cost systems. The 
JPBAFM

32,3

\begin{tabular}{|c|c|c|c|c|c|c|}
\hline Year & $\begin{array}{l}\text { Agencies should have } \\
\text { Cr. } 1 \\
\text { A specific } \\
\text { governance model }\end{array}$ & $\begin{array}{l}\text { Cr. } 2 \\
\text { Measurable } \\
\text { products and } \\
\text { services }\end{array}$ & $\begin{array}{l}\text { Cr. } 3 \\
\text { An administration } \\
\text { capable of producing } \\
\text { specific management } \\
\text { criteria }\end{array}$ & $\begin{array}{l}\text { Cr. } 4 \\
\text { Full cost } \\
\text { information and } \\
\text { cost systems }\end{array}$ & $\begin{array}{l}\text { Cr. } 5 \\
\text { Performance and } \\
\text { efficiency } \\
\text { measurement }\end{array}$ & $\begin{array}{l}\text { Cr. } 6 \\
\text { To comply with } \\
\text { other criteria }\end{array}$ \\
\hline $\begin{array}{l}1992- \\
1994\end{array}$ & $X$ & $\bullet$ & $X$ & $\mathrm{X}$ & - & $\mathrm{X}$ \\
\hline $1995^{1}$ & $X$ & $\begin{array}{l}\text { in quantity } \\
\text { and quality }\end{array}$ & $\begin{array}{l}\bullet^{2} \\
\text { based on accrual } \\
\text { accounting }\end{array}$ & $\begin{array}{l}\mathrm{X} \text { by insight in } \\
\text { budgeted and } \\
\text { actual costs of } \\
\text { production }\end{array}$ & $\begin{array}{l}\text { a real option to } \\
\text { work more } \\
\text { efficiently must } \\
\text { exist }\end{array}$ & $\mathrm{X}$ \\
\hline $1998^{4}$ & $\begin{array}{l}\text { entity should have } \\
\text { an external system } \\
\text { of planning and } \\
\text { control, connected to } \\
\text { an internal system } \\
\text { of planning and } \\
\text { control }\end{array}$ & $\begin{array}{l}\text { based on } \\
\text { described } \\
\text { business } \\
\text { processes }\end{array}$ & $\begin{array}{l}\text { based on accrual } \\
\text { accounting }\end{array}$ & $\begin{array}{l}\text { explicitly } \\
\text { related to Cr. } 2\end{array}$ & $\begin{array}{l}\text { by using full cost } \\
\text { information per } \\
\text { product or } \\
\text { service } \\
\text { and one or more } \\
\text { specified quality } \\
\text { indicators }\end{array}$ & $\mathrm{X}$ \\
\hline $2000^{6}$ & $\begin{array}{l}\text { entity should have } \\
\text { an external system } \\
\text { of planning and } \\
\text { control, connected to } \\
\text { an internal system } \\
\text { of planning and } \\
\text { control }\end{array}$ & $\begin{array}{l}\text { based on } \\
\text { described } \\
\text { business } \\
\text { processes }\end{array}$ & $\begin{array}{l}\text { based on accrual } \\
\text { accounting, agency } \\
\text { has to comply with } \\
\text { three conditions }\end{array}$ & $\bullet$ & $\begin{array}{l}\text { by using full cost } \\
\text { information per } \\
\text { product or } \\
\text { service } \\
\text { and one or more } \\
\text { specified quality } \\
\text { indicators }\end{array}$ & $\begin{array}{l}\text { an executed } \\
\text { scenery analysis }^{7}\end{array}$ \\
\hline $2002^{8}$ & $\begin{array}{l}\text { by an available } \\
\text { external system of } \\
\text { planning and } \\
\text { control, connected to } \\
\text { an internal system } \\
\text { of planning and } \\
\text { control }\end{array}$ & $\begin{array}{l}\text { based on } \\
\text { described } \\
\text { business } \\
\text { processes }\end{array}$ & $\begin{array}{l}\text { based on accrual } \\
\text { accounting, agency } \\
\text { has to comply with } \\
\text { five conditions }\end{array}$ & 0 & $\begin{array}{l}\text { by using full cost } \\
\text { information per } \\
\text { product or } \\
\text { service } \\
\text { and one or more } \\
\text { specified quality } \\
\text { indicators }\end{array}$ & $\begin{array}{l}\text { - } \\
\text { an executed } \\
\text { scenery analysis, } \\
\text { showing all } \\
\text { organizations } \\
\text { having a } \\
\text { governance } \\
\text { relation with the } \\
\text { agency }\end{array}$ \\
\hline & $\begin{array}{l}\text { Implicating } \\
\text { governance and } \\
\text { budgeting on } \\
\text { quality, quantity } \\
\text { and full costs }\end{array}$ & & & & & $\begin{array}{l}\text { Application of risk } \\
\text { management }\end{array}$ \\
\hline $2007^{9}$ & $\begin{array}{l}\text { contractualism and } \\
\text { result-based } \\
\text { steering, including } \\
\text { incentives to more } \\
\text { efficient production }\end{array}$ & $\bullet$ & $\begin{array}{l}\text { based on accrual } \\
\text { accounting, } \\
\text { compliant with five } \\
\text { conditions }\end{array}$ & $\begin{array}{l}\text { calculating with } \\
\text { all costs (direct } \\
\text { and indirect) }\end{array}$ & $\begin{array}{l}\text { by using } \\
\text { - agreements in } \\
\text { advance and } \\
\text { afterward about } \\
\text { performance } \\
\text { - audits and } \\
\text { benchmarking } \\
\text { - full cost } \\
\text { information } \\
\text { (long- run } \\
\text { development) }\end{array}$ & $X$ \\
\hline $\begin{array}{l}2011^{10} \\
2012^{11}\end{array}$ & $\begin{array}{l}\text { Equal to } 2007 \\
\text { contractualism and } \\
\text { result-based } \\
\text { steering, including } \\
\text { incentives to more } \\
\text { efficient production }\end{array}$ & Equal to 2007 & $\begin{array}{l}\text { Equal to } 2007 \\
\text { based on accrual } \\
\text { accounting } \\
\text { or } \\
\text { cash accounting }\end{array}$ & $\begin{array}{l}\text { Equal to } 2007 \\
\mathrm{X} \\
\text { (only linking } \\
\text { financial } \\
\text { expenditures to } \\
\text { performances) }\end{array}$ & $\begin{array}{l}\text { Equal to } 2007 \\
\text { by producing } \\
\text { more efficiently } \\
\text { than under its } \\
\text { former status } \\
\text { demonstrating } \\
\text { how this will be } \\
\text { achieved over the } \\
\text { next five years }\end{array}$ & $\begin{array}{l}\text { X } \\
\text { a business volume } \\
\text { of more than } € \\
50 \mathrm{mln} \\
\text { a sufficient level of } \\
\text { quality of the } \\
\text { financial } \\
\text { profession and } \\
\text { management }\end{array}$ \\
\hline
\end{tabular}

Table 1.

Criteria for the agency status 1992-2018 


\begin{tabular}{|c|c|c|c|c|c|c|c|}
\hline Year & $\begin{array}{l}\text { Agencies should have } \\
\text { Cr. } 1 \\
\text { A specific } \\
\text { governance model }\end{array}$ & $\begin{array}{l}\text { Cr. } 2 \\
\text { Measurable } \\
\text { products and } \\
\text { services }\end{array}$ & $\begin{array}{l}\text { Cr. } 3 \\
\text { An administration } \\
\text { capable of producing } \\
\text { specific management } \\
\text { criteria }\end{array}$ & $\begin{array}{l}\text { Cr. } 4 \\
\text { Full cost } \\
\text { information and } \\
\text { cost systems }\end{array}$ & $\begin{array}{l}\text { Cr. } 5 \\
\text { Performance and } \\
\text { efficiency } \\
\text { measurement }\end{array}$ & $\begin{array}{l}\text { To comply with } \\
\text { other criteria }\end{array}$ & parliamentarians \\
\hline $2018^{12}$ & $\begin{array}{l}\text { - } \\
\text { contractualism and } \\
\text { result-based } \\
\text { steering, including } \\
\text { incentives to more } \\
\text { efficient production }\end{array}$ & 0 & $\begin{array}{l}\text { based on accrual } \\
\text { accounting, but only } \\
\text { when there is a } \\
\text { depreciation rate of } \\
\text { at least } 5 \% \text { of the } \\
\text { average business } \\
\text { volume in the last } 3 \\
\text { years, } \\
\text { otherwise } \\
\text { cash accounting }\end{array}$ & $\begin{array}{l}\mathrm{X} \\
\text { linking financial } \\
\text { expenditures to } \\
\text { performances }\end{array}$ & $\begin{array}{l}\text { by producing } \\
\text { more efficiently } \\
\text { than under its } \\
\text { former status } \\
\text { demonstrating } \\
\text { how this will be } \\
\text { achieved over the } \\
\text { next five years }\end{array}$ & $\begin{array}{l}\text { a business volume } \\
\text { of more than } € \\
50 \text { mln } \\
\text { a sufficient level of } \\
\text { quality of the } \\
\text { financial } \\
\text { profession and } \\
\text { management }\end{array}$ & \\
\hline
\end{tabular}

Note(s): = obligated $\mathrm{X}=$ not mentioned

${ }^{1}$ Formally described in 1994 by the 6th amendment of the national accountability law: Tweede Kamer, 19931994, 23.769, nr.3. Exception is the obligation to use accrual accounting, which was extra amended by the Parliament while debating the 6th amendment: Tweede Kamer, vergaderjaar 1994-1995, 23,796, nr. 39, pp. 2,704-2,705.

${ }^{2}$ Secured by a consented auditor's certificate.

${ }^{3}$ Full cost information or cost system is not mentioned.

${ }^{4}$ Verder met resultaat; het agentschapsmodel 1991-1997, Ministerie van Financiën, April 1998.

${ }^{5}$ Only mentioned in the national accountability law.

${ }^{6}$ Tweede Kamer, vergaderjaar 1999-2000, 26,541/26,627, nr. 70, 10 februari 2000, pp. 17-19. In fact, the criteria were more specified than in 1998 and presented in this table.

${ }^{7}$ A scenery analysis shows the environment of an agency in terms of roles (principal, agent, owner, funder and supervisor) and responsibilities (decision-making, funding and consuming). Hereby, also funding sources and information channels are discussed (refer to Tweede Kamer 1999-2000, 26,541/26,627, 10 februari 2000).

8 Tweede Kamer, 2002-2003, 28,737, nr.1. 16 December 2002.

${ }^{9}$ Regeling Baten-Lastendiensten, 2007

${ }_{11}^{10}$ Regeling Baten-lastendiensten, 2011

${ }^{11}$ Regeling Agentschappen 2012

${ }^{12}$ Regeling Agentschappen 2017

Table 1.

fifth criterion "performance and efficiency measurement" deals with the topic of operating more efficiently, and finally, the last category contains some miscellaneous requirements.

It should be noted that our four selected NPM themes are strongly related and are an important fundament for the appliance of the Dutch agency model. The governance model not only includes the responsibilities of the agency's management but also the agency's formal relation with the principals within the parent ministry. The use of accrual accounting for reporting purposes is related to full cost information and cost systems. If managers and other stakeholders need to make product-costing decisions then full cost information is necessary (Schoute and Budding, 2017). They also need this information for operational control purposes. An accrual accounting system adds to the quality of full cost information (Christiaens and Rommel, 2008). However, using an administration based on accrual accounting was not compulsory at the start of the agency model in 1994, as we will show later on in this paper. Having full cost information and a cost system are crucial conditions for the ability to measure efficiency. Over time, full cost information played an important role in trying to make the agency model effective. We already mentioned that increasing efficiency seemed to be the most important objective of the introduction and establishment of agencies in the early 1990s. Even today the Ministry of Finance prescribes efficiency both in the regulation and on its website [10]. 
JPBAFM 32,3

428

As mentioned earlier in this paper, the executive agence governance model has much in common with what Pollitt et al. (2004) call the tripod model. From 1998 onwards the use of internal and external planning and control model was made mandatory. Later on this was extended with the requirement that using a planning and control model should also lead to control on quality, quantity and full cost information. It was only in 2007 that the regulation stipulated that performance management should be based on contractual relationships. But even here the last adjustment of the Regeling agentschappen, a special regulations document (also named "de Regeling baten-lastendiensten"), made it possible to develop and use a governance model that counts with the specific circumstances in which an agency operates.

If we look at financial reporting practices, we observe that agencies initially could choose between conducting a cash administration or an administration based on accrual accounting, but as a result of an intervention by the Parliament from 1996 onwards agencies had to use accrual accounting reporting. Furthermore, in 2000 several new elements were prescribed, such as the requirement to prepare an opening balance sheet and to have a financial statement audit. From 2011 onwards, executive agencies did not have to use accrual accounting anymore.

From 1998 onwards, executive agencies should use full cost information and cost systems. In 2012, the regulation was relaxed and from then on only the link between spending and performance should be made explicit.

As discussed earlier, an important driver for introducing executive agencies was the expectation that efficiency improvements could be realized. However, in the first years of the model gaining efficiency improvements was not a formal criterion for setting up an agency. Only from 1995 onwards agencies had to prove that they expected to be able to work more efficiently than they did under their pre-agency status.

Efficiency remained an important criterion over the years, although the descriptions changed. In 1998, a direct link was made between efficiency and the use of full cost information per product or service, i.e. the use of the latter was expected to improve the former. In 2007, this was broadened to the use of benchmarks and audits. After the last general evaluation in 2011, however, the requirement to use full cost information, benchmarks or audits to show efficiency improvements was replaced by much more general prescriptions. This still placed the emphasis on improving efficiency but in a way that was more realistic and therefore, possible to achieve.

Over the years, we see that the criteria developed from more global to more detailed prescriptions and turning to more global prescriptions again in 2012.

\section{General evaluations and Parliament interventions \\ Evaluations and questions by the Parliament}

Very soon (i.e. in January 1995) after the first introduction of the executive agency model, the Dutch cabinet announced an evaluation of the agency construction [11]. This first general evaluation appeared in 1998 and was succeeded by evaluations in 2002, 2005 and 2011. In this section we analyse these four general evaluations in relation to the questions submitted by MPs in advance of the debate with the Minister of Finance and questions asked by MPs during these debates. Appendix 1 provides some more information about the research method used.

In total, we found 127 questions that we split into nine themes based on their content [12]. A total of six of these themes (the first six numbers in Table 2) are derived from the key elements that are part of the mandated criteria, as developed since 1994 (see Table 1). The last category ("miscellaneous") contains questions concerning several subjects, such as the difference between a state-owned company and an agency but also the methods of evaluation and naming of agencies. Another special category is that of temporary agencies: in 2001 
autonomous administrative authorities were offered the opportunity to acquire a temporary agency status when they became part of the central government organization again. This led to many questions from the Parliament: $16 \%$ of the submitted and asked questions pertained to this subject.

As mentioned before, in this paper we focus on four themes: (1) governance model, (2) accrual accounting, (3) full cost information and cost systems and (4) efficiency. These themes jointly account for 42 questions, of which more than $50 \%$ are related to accrual accounting and efficiency. These themes will be discussed below. The other questions mainly concerned the establishment criteria in general (17 questions), the temporary agency status (20 questions) and the miscellaneous category (36 questions).

\section{The governance model}

The governance model of agencies was originally based on a result-driven steering and control model containing criteria such as using integral management and performance contracts. Later on, principal-agent relationships were introduced. Within the Dutch central public sector this was extended to a model in which the agency model actually maintains two relationships: one with the so-called owner, who is responsible for the continuity of the agency and one with the client, commissioning the agency to implement and execute policy. The idea behind the concept is that the model stimulates efficiency and quality with a client who wants to pay as little as possible to the agency for executing policy and an owner who stands for long-term quality of the agency's organization. This specific model was already used by Senter, one of the first agencies that started in 1994 (Buijink and Heutink, 1996). The model operated until 2007 before it was formalized in de Regeling baten-lastendiensten and officially became one of the mandated criteria.

In the daily practice, the model was not always easy to apply for several reasons. First, not all agencies can be classified as strict implementers of policy but rather fulfilling self-assigned statutory duties. Therefore, the role of client cannot be conducted in a serious way. Second, although many departments still make the distinction between "owner" and "client" in relation to agencies, it seems to be quite difficult to operationalize the model especially when owner and client are participating in the same policy area and will have the same goals in relation to the agency. In that case, the two roles are concentrated in one single official.

The evaluation of the Dienst Justitiele Inrichtingen (Custodial Institutions Agency) in 2014 focused attention on the application of the governance model in the relation between the agency and policy departments of the Ministry of Justice and Security. Owner and client on the one hand, and the agency on the other, experienced different aspects of the application in which the policy department concentrated the roles of owner and client in one. The agency paid too little attention to the role of owner while the policy department focused too much attention on this role.

\begin{tabular}{|c|c|c|c|c|c|c|c|}
\hline & 1992 & 1998 & 2001 & 2002 & 2005 & 2011 & TOTAL \\
\hline 1. Governance model & 1 & & & & & 7 & 8 \\
\hline 2. Accrual accounting and administration & 4 & 4 & & 3 & & 1 & 12 \\
\hline 3. Full cost information and cost systems & & & & 8 & 1 & 1 & 10 \\
\hline 4. Efficiency & & 2 & & 6 & 1 & 3 & 12 \\
\hline 5. Performance indicators & & & & 2 & & 1 & 3 \\
\hline 6. Budgeting and financing & 1 & 2 & & 5 & & 1 & 9 \\
\hline 7. Establishment criteria in general & 2 & 6 & & 8 & & 1 & 17 \\
\hline 8. Temporary agency status & & & 13 & 7 & & & 20 \\
\hline 9. Miscellaneous & 7 & 3 & & 19 & & 7 & 36 \\
\hline TOTAL & 15 & 17 & 13 & 58 & 2 & 22 & 127 \\
\hline
\end{tabular}

The influence of parliamentarians 
JPBAFM 32,3

\section{(Reference: Doorlichting Dienst Justitiële Inrichtingen, Ministerie van Financiën, April 17, 2014)}

Experiences with the roles of owner and client led to the fact that in the "Regeling agentschappen 2012" the application of the principal-agent model was still a recommendation, but deviations were accepted as legitimate variations of the model.

Over the years, the Parliament gave little attention to the governance model. It was only in the last review of 2011 that more attention was given to the model and seven questions were asked on this subject during the debate on the 2011-evaluation, in which three of them focussed on the knowledge and motivation of the actors who fulfilled one of the roles in the model. Also, two questions concerned the supervision of the Ministry of Finance and the departments at the agencies. In advance of the debate with the Parliament, changes in the governance model were proposed. As far as the governance model is concerned, it seems that experiences in the daily practice led to adjustments and finally weakened the regulations but without direct intervention by the Parliament.

\section{Accrual accounting}

Although only twelve questions $(9 \%)$ were submitted and asked during debates on the general evaluations of the agency model were about accrual accounting, the Parliament played an important role in discussing the subject. At the start of the executive agency model in 1994, agencies could choose between cash accounting and accrual accounting as the basis for their accounting system, but - due to an intervention by the Parliament - accrual accounting became mandatory for all agencies from 1995 onwards. The concerned MPs considered that by giving free choice for an accounting system, the risk of creating a hybrid system of accounting systems within central government departments would be a problem. Accrual accounting continued to attract attention, especially since 2002 when the question was raised whether all departments and organizations of the Dutch Central Government had to use accrual accounting, as it was already applied by and mandatory for all local governments from the 1980s onwards.

Reading the history of agencies in The Netherlands we notice a remarkable focus on the expansion of using accrual accounting. Some academics (e.g. Minderman, 2000) thought that the agency model was a vehicle for introducing accrual accounting in central government departments as a whole. The use of accrual accounting by agencies enabled central government departments to get experience with this system in anticipation of - probably - a broader introduction, but the latter was in fact never realized.

The 1998 general evaluation concluded that accrual accounting was of great added value for the participating agencies. In particular, investment decisions could be taken on more economical grounds [13]. The 2011-evaluation, however, stated that using accrual accounting seemed not to have delivered a big contribution to the increase in efficiency and governance of the agencies. The study showed that the depreciation rate of most agencies did not exceed $5 \%$, indicating that the average level of investments was rather low [14]. Besides that, the evaluation also mentioned that the costs of implementing accrual accounting systems ranged between $€ 13$ and $€ 35$ million. For those reasons the report advised that accrual accounting had to be applied only in those situations in which it had significant economic advantages.

\section{Full cost information and cost systems}

Having full cost information is a crucial condition for the ability to measure efficiency. Over time, full cost information played an important role in trying to make the agency model effective. The calculation of full cost information and the use of it, however, cannot be done without predefined and produced services and products. During 1994-1998, prescriptions did not explicitly mention cost systems, but their necessary use could be derived from the prescription to define and use measurable products and services. 
Although the first general evaluation (1998) concluded that 13 out of the 14 existing agencies had defined products and services, it became clear that identifying and clearly defining products and services remained a continuous process. In addition, the possibility to describe products and services is complicated by the fact that the products' content can change (for example, by changed policy of regulations) [15]. Because of this, another way of presenting costs became more obvious, for example, using rates per hour [16].

"The evaluation of the (no longer existing) Agency for Infrastructure Inspection (IVW) clearly revealed that during the pre-agency status a lot of time was spend in developing a cost system; the presumed The influence of parliamentarians homogeneity of output was much less strong than initially thought. As a consequence, over time, costs were reported more and more at a higher level of the organization and became more abstract. Also, the question may be whether or not too many products and services were defined in advance, which made an effective method for calculating full cost information only more complex".

(Reference: Evaluatie baten-lastendienst Inspectie V\&W, Ministerie van Verkeer en Waterstaat, June 6, 2012)

From 1998 onwards, the use of cost systems was explicitly prescribed, but models varied with big differences in accuracy. The 2011-evaluation showed that $43 \%-19$ of the 44 agencies analysed - used full cost information, while $50 \%$ of the agencies used rates per hour as an efficiency indicator [17]. In addition to output definitions, several agencies also developed quality indicators. In the daily practice $77 \%$ of all agencies used quality indicators [18]. So, quality indicators seem to be more frequently used than full cost information.

Over time, MPs asked ten questions about full cost information and cost systems. In debating the 2011-evaluation some MPs raised the question of whether agencies which were having difficulty in calculating full cost information, should be using accrual accounting. The Minister of Finance replied that using accrual accounting was "a one-sizefits-all 'fashion' model". "In practice," he continued, "it cannot be applied consistently because the demand for and the type of products and services and the environment seem to be very different. Using full cost information, which the model is based on, therefore is limitedly workable. Because of that reason, the government wants to give more room for custom-made solutions by allowing annual agreements, based on input funding, instead of the currently mandated output budgeting. The condition remains, however, that there must be a clear cost structure on the basis by which annual agreements can be made. However, a far-reaching specification of products and services, as well as full cost information per product is no longer required in all cases" [19].

Note that the 2011-evaluation also observes that cost systems often become too detailed to be useful and causes more costs itself than can be justified.

Although the current regime allows agencies to apply other ways of funding than output budgeting, the latter is still used as a guiding model. The cost system is nevertheless used less strictly as a standard and no longer explicitly prescribed. Nowadays, an assessment of the application for agency status takes place at a higher abstraction level. The Regeling agentschappen only mentions "price agreements" in relation to "performance to be delivered". It should be remarked, however, that price agreements do not have to be based on full cost information.

\section{Efficiency}

As already discussed, the expectation that the implementation of executive agencies would lead to performance improvements was an important driver of introducing this form of administration. Simultaneously, the possibility to gain efficiency improvements was also a formal requirement for central government departments to obtain the agency status. This multifunctional purpose of efficiency shows its importance in discussions about agencies and agencification in The Netherlands. 
JPBAFM 32,3
The report "Verder bouwen aan beheer", contained the Dutch word for efficiency once or more on almost every page. At the beginning of 1992, the Dutch Parliament discussed the report with the Minister of Finance. Preceding this debate, MPs submitted more than 60 questions about the report. A total of 15 of these questions concerned agencies, including four questions asked during the discussion, but none of them regarded efficiency. Most striking was the warning of one of the MPs to be cautious with all forms of internal and external autonomizations, because experiences in other countries showed that performance improvements were very hard to obtain [20].

According to the first general evaluation report, published in 1998, for seven of 14 existing agencies time was too short to come to reliable conclusions about efficiency improvements. For the other seven agencies, there seemed to be clear indications that efficiency improved over time. The authors of the report indicated that scientifically reliable conclusions about the volume of the achieved efficiency, however, were hard to draw. Even if they could, it would be hard to prove that efficiency improvements were a direct outcome of the agency status [21]. Furthermore, the researchers claimed to have found a culture change, in the sense of more cost consciousness. In their debate about the evaluation, MPs criticized the fact that the evaluation was conducted by civil servants and not by an independent research team or institute. During the debate, MPs also concentrated on the lack of administrative organization in the agencies [22]. Despite the fact that the Parliament received the evaluation rather skeptically, there was not much focus on the theme of (improved) efficiency. Only two questions were about efficiency, one concerning the effect of using accrual accounting on efficiency and the second asking the minister to do more research on efficiency gains [23]. The evaluation report suggested to change the implementation criteria for executive agencies and prescribed that agencies should make a more explicit relation between full cost information and products or services in order to make efficiency more measurable.

In the second general evaluation (2002), the Ministry of Finance relaxed the claim that the agency status had led to performance improvements. The main findings of the study were formulated as follows: "the agency model contributes to a more efficient execution because the critical success factors that contribute to an efficient operational management are part of the model and the conditions for implementation" [24].

While the debate between the Parliament and the minister was dominated by the possibility of a broad introduction of accrual accounting within central government departments, MPs were very critical about the agency status, but even now their questions did not specifically focus on efficiency. A total of 58 questions were submitted and asked, but only six question concerned this theme [25], hereby focusing on the minister's statement that it was his wish to create more agencies because of their ability to work more efficiently. Meanwhile, a report by external consultants stated that a more efficient way of production could not be proven for about $70 \%$ of the agencies. The minister replied that this did not mean that the agencies concerned would have worked more efficiently if they had not been agencies [26].

Three years later, in 2005, the Minister of Finance was rather. In a letter to the Parliament, he stressed the fact that it remained complicated to relate output and quality of services delivered to the means spent. His conclusions were based on a test that analysed the way current agencies complied to the criteria of 2002. Also, two years later criteria concerning efficiency were once again changed, specifically by demanding agencies to make explicit how they will improve efficiency.

In 2008, the Dutch Central Government commissioned the Organisation for Economic Cooperation and Development (OECD) to conduct a study aiming to identify new developments in the organization of central government that could lead to better value for money and better services at lower costs for taxpayers. The OECD study which was partly based on interviews with Dutch officials, was published in 2011, slightly before the publication of the evaluation 
report of the Ministry of Finance in August that year. In fact, the OECD gave the Dutch Central Government a first recommendation to focus less on output budgeting (and use capacity budgeting instead) and to apply input budgeting when useful and necessary.

The general evaluation of 2011, by the Ministry of Finance, was conducted by using information from publicly available budgets and annual reports, earlier evaluations of individual executive agencies, scientific literature, interviews and expert meetings and case studies of ten executive agencies. The agencies were evaluated on four dimensions: resultsoriented governance, (measurable) efficiency, the need for a divergent financial regime and autonomy of operational management [27]. In some cases, it seemed hard to define output. Conditions for using full cost information and output budgeting could therfore not always be fulfilled. Only in a few cases, the cost system was found to function as intended. As a result, efficiency was also almost impossible to measure. Although the report was rather critical in several ways, one of its conclusions was that, although it could not be proven, the model worked positively on cost awareness and cost reduction. The minister stated that: "The evaluation indisputably shows that the introduction of internally autonomized agencies, and the corresponding separation of policy and execution including the results-oriented control model, has led to an improved cost consciousness and more accountability', but '. . . it was found difficult to show efficiency improvements at agencies in a quantitative way, [28]”.

Furthermore, the minister declared that,"nevertheless, it could be said that as a result of task settings (i.e. general budget cuts, authors) also at executive agencies ... improved efficiency is realized" [29]. This seems to be in contrast to the statement that efficiency improved because of the agency model and not because of the benefits of general budget cuts. Efficiency is also hard to prove when products and services are not stable overtime. The latter is very important; public products and services are often subject to legal prescriptions. Changes in these prescriptions change the character of products and services over the years in a way that makes a comparison almost impossible. Even MPs pointed to this problem, submitting three questions on efficiency and focusing on the report's statement that efficiency indicators were unreliable over the years.

In sum, it can be concluded that although MPs did not focus primarily on efficiency during debates this was a central element of the overall conclusions of the various evaluation reports and the statements of the various Ministers of Finance. Despite the critical tone, the first and second evaluations stubbornly hold on to the view that the agency status had a positive impact on efficiency and cost awareness. However, several adjustments that were mandated to the criteria, as mentioned in Table 1, also indicate that government struggled with the efficiency issue.

\section{Conclusions}

Inspired by scholars' calls for further research on politicians' involvement and influence on public sector reforms (Van Helden, 2016), we conducted a desk research on executive agencies introduced into the Dutch Central Government during the early 1990s. Our main research goal was to explore which role politicians play in the process of lawmaking and changing, as far as financial management techniques are concerned. In our study, we analysed how the prescriptions for executive agencies developed over time, hereby focussing on how formal evaluation studies were discussed in the Parliament and how these discussions influenced the prescriptions. We restrained our analysis to four themes that are important elements of both NPM thinking and criteria for the establishment of executive agencies: (1) governance model, (2) accrual accounting, (3) full cost information and cost systems and (4) efficiency.

We found that MPs submitted and asked 127 questions on agencies, regarding the establishment of the agency model, general evaluations and policy changes in the period of 
JPBAFM 32,3

more than 25 years, 1992-2018. About $42(33 \%)$ of these questions considered the aforementioned four themes. From these questions, eight were about the governance model, twelve about accrual accounting, ten about full cost information and twelve were about efficiency.

While efficiency improvements were and still are the main goal of the agency model, it is a bit surprising that only twelve questions concerned efficiency and only ten address full cost information. Another topic that did not attract much attention was the governance model. In total, eight questions were asked on this subject, almost all (seven) after the general evaluation of 2011. For these three themes, we did not observe changes in regulation after the debate in the Parliament. We only find such a change for the final theme, i.e. accrual accounting. Through the intervention of one MP, accrual accounting became compulsory for all agencies from 1996 onwards. A possible explanation for this is that at that time using accrual accounting by agencies was seen as a pilot for a broad implementation of this system within the entire Dutch Central Government. However, the general evaluation of 2011 was rather critical about the added value of accrual accounting for executive agencies and as of today, accrual accounting is not implemented in Dutch Central Government ministries.

Regarding the four general evaluations and the influence of the Parliament, it is remarkable that most of the adjustments on the criteria were already formulated in advance of debates with the Parliament. There seemed to be no significant influence from the Parliament on changing the criteria, except the requirement for agencies to use accrual accounting as their general system for financial administration. Although there were no fundamental general objections in the Parliament to the introduction and application of the agency model, several MPs warned about a quick broad application of the agency model and pleaded to evaluate the developments first. Despite these warnings and at best only "indications for efficiency improvements", the number of agencies grew very quickly.

In line with the findings of other studies (e.g. Hyndman and Liguori, 2016), we observe that more than 25 years after the implementation of executive entities the control and governance characteristics of executive agencies are still based on NPM thinking. Therefore, the question Verhoest (2018) puts forward in a recent publication, i.e. if governance arrangements of agencies reflect pure archetypical agency governance models (pre-NPM, NPM and post-NPM) or if they are hybrid arrangements as a result of layering of different agency models, can be answered in the Dutch case as being primarily NPM-based. Although hard evidence is missing, we have the impression that the rather moderate conclusions of the evaluation studies played a role in this.

This does not imply, however, that the regulation was stable in the observed time period. Instead, we rather found substantial changes. Starting from more "general" and "broad" terms in the early 1990s, the regulation became more "specific" and "detailed" during the next 15 years. However, after the most recent formal evaluation of executive agencies, the criteria are once again stated in general and broad terms. In order to explore how this development can be explained, we asked a group of four (former) senior civil servants, who were all previously involved in the introduction of the agency model, for their opinion on this issue. Although their views varied, they also had some common thoughts. During the initial years of working with the executive agency model regulation seem to have been deliberately kept general: the intention was to make the agency model widely accessible and also to gain experience with it. As a result of the first evaluation, criticism on agencies increased, and regulations became more specific and detailed, aiming to increase the quality of the model. Our respondents came up with two possible explanations of the relaxing of the criteria in 2012. The first is a diminishing focus on NPM-based instruments in central government in general, and the second less belief in the executive agency model in specific. The publication of the previously mentioned OECD study in 2011, which was partly based on interviews with 
Dutch senior government officials and advised to move partly from output budgeting to input budgeting, was a good indication for this.

This study is not without limitations. First, in our desk research we only used official documents, such as minutes of meetings in the Parliament, official reports and letters to the Parliament. The merit of using these documents is that these are validated documents. However, using only desk research refrained us from being able to ask questions to delve deeper into the motives of politicians for their positioning towards agencies in general and their role towards financial management regulation in specific. Our study is therefore primarily exploratory in nature. Future studies can deepen our analysis on this. Second, our further exploration of the reasons for the development of the criteria is quite limited and can be extended.

Nevertheless, we found that the influence of political discussion on the adjustments of the prescriptions for executive agencies was quite small. This was even so in a period in which substantial NPM-inspired changes were implemented. This is surprising as MPs are the ultimate responsible party for the making and changing of laws, including those that relate to financial management practices. Furthermore, politicians belong to the main stakeholders of financial management rules as it is this regulation that determines how information is provided to them, and how they can exercise control. As a result of this, the interests and needs of MPs, may not be taken enough into consideration, giving the risk that they can do their work less efficiently and effectively.

We advise to further explore how MPs pick up their role in the process of lawmaking and changing, as far as financial management techniques are concerned. We also recommend analysing how the involvement of politicians on financial management issues can be enlarged. We think this is a joint responsibility of multiple parties and we suggest several avenues. First, the Ministry of Finance could emphasize more explicitly the significance of financial management regulation to MPs. Second, political parties can pay more attention to the recruitment of MPs with financial management expertise. Third, the support of MPs on more technical (and less political) matters can be enlarged so that they can participate better prepared in debates about such issues.

\section{Notes}

1. Following Schoute and Budding (2017), we use the terms full cost information and cost systems as the English equivalents of the Dutch terms integrale kostprijs and kostprijsmodel.

2. This does not mean that the number of agencies grew continuously over the years; mergers between agencies occurred as well; https://www.rijksoverheid.nl/documenten/brochures/2017/05/17/ agentschappen-in-beeld-2016.

3. Tweede Kamer, vergaderjaar 2002-2003, 28.737, nr. 1, p. 3

4. Tweede Kamer 1991-1992, 22.300, No. 1, p. 315.

5. 27e Vergadering Commissie voor de Rijksuitgaven, February 17, 1992, p. $27-36$.

6. Nowadays called the Minister of Interior and Kingdom Relations.

7. Ministers of Finance and the Interior, letter dated June 25, 1992.

8. Plantenkundige Dienst (Agriculture department), Duyverman Computer Centrum (Defense department), IND (Justice department) and Senter (Economic Department).

9. Vergaderstukken Eerste Kamer 23.796.

10. Refer to https://www.rijksoverheid.nl/onderwerpen/rijksoverheid/agentschappen, most recently accessed on May 5, 2019, where it is mentioned that the executive agency model should lead to performance improvements.

11. Tweede Kamer, vergaderjaar 1994-1995, 23.769, nr. 8 
JPBAFM 32,3

12. We could not find any document with submitted questions of the 1998 evaluations in the digital archive of the Dutch Parliament.

13. Verder met resultaat; het agentschapsmodel 1991-1997, Ministerie van Financiën, April 1998, page 38 .

14. From 2012 a depreciation rate, exceeding $5 \%$ of total costs, calculated for three years is prescribed.

15. Page 43 of the 1998 evaluation.

16. For example with one of the first agencies, see page 43 of the 1998-evaluation.

17. Page 25 of the 2011-evaluation.

18. Page 27 of the 2011-evaluation

19. Tweede Kamer, vergaderjaar 2011-2012, 28.737, nr. 22 10, pp. 10-11.

20. 27e Vergadering: Commissie voor de Rijksuitgaven, February 27., 1992, pp. $27-8$.

21. The same conclusion occurred in a survey conducted by civil servants of the Custodial Institutions Agency - the Dienst Justitiële Inrichtingen (Taphoorn et al., 1998).

22. This was also confirmed in a separate survey conducted by the Court of Audit.

23. Tweede Kamer 1998-1999, 25.257 25, 509, p. 2

24. Tweede Kamer, vergaderjaar 2002-2003, 28.737, nr. 1, p. 3

25. Tweede Kamer, 2002-2003, 28.737 23.171, p. 2.

26. Tweede Kamer, vergaderjaar 2003-2004, 28.737 en 23.171, nr. 5, p. 6

27. Three of these dimensions relate to our four themes: results-orientated governance to the governance model, (measurable) efficiency to efficiency and the financial regime to accrual accounting.

28. Tweede Kamer, vergaderjaar 2010-2011, 28.737, nr. 21, p. 2

29. Tweede Kamer, vergaderjaar 2011-2012, 28.737, nr. 22 p. 5.

30. The analysed documents are available from the authors upon request.

\section{References}

Birckland, T.A. (2005), An Introduction to the Policy Process: Theories, Concepts and Models of Public Policy Making, 3rd ed., Armonk, M.E. Sharpe, New York.

Buijink, C.P. and Heutink, G. (1996), "Het agentschap Senter", in Coops, R.H., Pauw, B.M.J., Van Rooy, Y.C.M.T. and Weitenberg, J., Van Overheid Naar Markt: Theorie, Praktijkenanalyse, SDU, Den Haag.

Christiaens, J. and Rommel, J. (2008), "Accrual accounting reforms: only for businesslike (parts of) governments”, Financial Accountability \& Management, Vol. 24 No. 1, pp. 59-75.

Groot, T.L.C.M. and Budding, G.T. (2008), "New public management's current issues and future prospects", Financial Accountability and Management, Vol. 24 No. 1, pp. 1-12.

Hood, C.C. (1995), “The 'New Public Management' in the 1980's: variations on a theme”, Accounting, Organizations and Society, Vol. 20 Nos 2/3, pp. 93-109.

Howlett, M., Ramesh, M. and Perl, A. (2009), Studying Public Policy, Policy Cycles and Policy Subsystems, 3rd ed., Oxford University Press, Oxford.

Hyndman, N. and Ligouri, M. (2016), "Public sector reforms: changing contours on an NPM landscape", Financial Accountability and Management, Vol. 32 No. 1, pp. 1-33.

Hyndman, N., Liguori, M., Meyer, R., Polzer, T., Rota, S. and Seiwald, J. (2014), "The translation and sedimentation of accounting reforms. A comparison of the UK, Austrian and Italian experiences", Critical Perspectives on Accounting, Vol. 25 Nos 4-5, pp. 388-408. 
Lægreid, P. and Verhoest, K. (2010), Governance of Public Sector Organizations, Proliferation, Autonomy and Performance, Palgrave Macmillan, Houdmills.

Lapsley, I. (2009), "New Public Management: the cruelest invention of the human spirit", Abacus, Vol. 45 No. 1, pp. 1-25.

Liguori, M., Siciliana, M. and Steccolini, I. (2009), "Politicians versus managers: roles and interactions in accounting cycles", International Journal of Public Sector Management, Vol. 22 No. 4, pp. 310-323.

Minderman, G.D. (2000), Tweede Kamer en rijksfinanciën, een studie naar parlementaire sturing van rijksfinanciën in Nederland, Juridische uitgeverij Boom, Den Haag.

Moore, M. (1995), Creating Public Value, Cambridge University Press, Cambridge.

Osborne, S. (2006), “The new public governance?", Public Management Review, Vol. 8 No. 3, pp. $377-387$.

Pollitt, C. Talbot, C., Caulfield, J. and Smullen, A. (2004), Agencies - How Governments Do Things through Semi-autonomous Organizations, Palgrave Macmillan, Basinstoke.

Regeling Baten-Lastendiensten (2007), Staatscourant, No. 42, pp. 9-28.

Regeling Baten-lastendiensten (2011), Staatscourant, No. 2,807.

Regeling Agentschappen (2012), Staatscourant, No. 20, p. 668.

Regeling Agentschappen (2017), Staatscourant, No. 69, p. 103.

Schoute, M. and Budding, G.T. (2017), "Stakeholders' information needs, cost system design, and cost system effectiveness in Dutch local government", Financial Accountability and Management, Vol. 33 No. 1, pp. 77-101.

Taphoorn, R.T.G., Paalman, K. and van der Meulen, H.J. (1998), "Twee jaar agentschap: doelmatigheid bij de Dienst Justitiële Inrichtingen”, Openbare Uitgaven, Vol. 30 No. 1, pp. 32-41.

ter Bogt, H.J. (1999), "Financial and economic management in autonomized Dutch public organizations", Financial Accountability and Management, Vol. 15 Nos 3/4, pp. 329-351.

Van Helden, J. (2016), "Literature review and challenging research agenda on politicians' use of accounting information”, Public Money and Management, Vol. 36 No. 7, pp. 531-538.

van Thiel, S. (2004), "Quangos in Dutch government", in Pollitt, P. and Talbot, C. (Eds), Unbundled Government: A Critical Analysis of the Global Trend to Agencies Quangos and Contractualisation, Routledge, London, pp. 167-183.

Van Helden, G.J. and Jansen, E.P. (2003), "New public management in Dutch local government”, Local Government Studies, Vol. 29 No. 2, pp. 68-88.

Verhoest, K. (2018), "Agencification in europe", in Ongaro, E. and van Thiel, S. (Eds), The Palgrave Handbook of Public Administration and Management in Europe, Palgrave Macmillan, London.

Wellstead, A. and Stedman, R. (2015) "Mainstreaming and beyond: policy capacity and climate change decision making", Michigan Journal of Sustainability, Vol. 3, pp. 47-63.

\section{Appendix 1}

\section{The research method}

In this paper, we use two kinds of documents. First, general evaluation reports (published in 1998, 2002, 2005 and 2011) were studied. Second, questions about these evaluation reports submitted by MPs in advance of debates, as well as during these debates were analysed [30].

We divided these written and spoken questions into nine categories which were primarily based on the establishment criteria for executive agencies (refer to Table 2). Table A1 provides selection criteria and examples for our classification.

We took several measures to secure the robustness and reliability of our analysis. First, all documents were analysed comprehensively two times. Second, several discussions took place between the authors of this paper about the allocation of the questions to the groups. 
JPBAFM 32,3

1. Governance model

2. Accrual accounting and administration

438

3. Full cost information and cost systems

4. Efficiency

5. Performance indicators

6. Budgeting and financing

7. Establishment criteria in general

8. Temporary agency status

Table A1.

9. Miscellaneous

Selection criteria and examples
The question contains one of the following topics: positioning of the agency within the Central Government and its relation to the parent ministry, the role and tasks of the owner, general accountability and control issues, the way in which the agency is subject to supervision and control Questions about the financial reporting system (cash or accrual-based)

The question concerns topics like cost measurement systems, the calculation of use of full cost information, cost systems, etc.

The word "efficiency" is used and is the main topic of the question Questions about quality and effectiveness indicators, as well as indicators about the agencies' production process

Questions about resources for operational costs of the agency, financing arrangements, balance sheet obligations (i.e. the maximum amount of reserves)

Questions about general criteria and conditions mandatory for gaining the agency status. When the question is about a specific criterion, it is allocated to one of the above-mentioned categories

Questions about the temporary agency status; in 2001, autonomous administrative authorities were offered the opportunity to acquire this status

All questions concerning several topics, not being part of the categories mentioned above, e.g. differences between state-owned companies and agencies, methods of evaluation and naming of agencies

\section{Corresponding author}

Tjerk Budding can be contacted at: g.budding@vu.nl

For instructions on how to order reprints of this article, please visit our website: 